\title{
Em memória \\ de Lívio Teixeira
}

BENTO PRADO JUNIOR

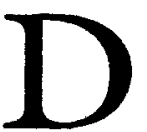

epois do choque, mas ainda perplexo, que pode $o$ antigo aluno senão buscar, na estante, os livros? Com a obscura sensação de um desencontro (o telefonema que anuncia a morte e cancela, para sempre, a visita planejada), abro a Doutrina dos Modos de Percepfão e o Conceito de Abstrafáo na Filosofia de Espinosa, o livro mais manuseado e anotado, o principal instrumento de trabalho no curso sobre Espinosa, naquele ano de 1957. Em seguida, o Ensaio sobre a Moral de Descartes, lido mais tarde, ao mesmo tempo que o Descartes selon l'Ordre des Raisons de Martial Guéroult, com quem trabalhara Lívio Teixeira (1902-1975). É outro livro que se abre à leitura renovada, como se o desaparecimento do Autor modificasse sua natureza. Antecipo em mim a leitura que será dos outros, dos que não chegarão a ele através ou depois da palavra viva do Professor. Não que minha leitura anterior fosse melhor, por poder continuar, fora do texto, na presença - ela era diferente e talvez mesmo menos completa, porque afetada por uma excessiva proximidade. $O$ discurso do mestre era mais da ordem do horizonte ou da atmosfera e só agora se cristaliza, para mim, como obra. Com esta mudança não se apaga todavia, imagino, para os novos leitores o perfil de Lívio Teixeira, para aqueles que não tiveram a oportunidade de vê-lo ou de ouvi-lo. Paradoxalmente, ele se torna tanto mais nítido quanto mais se dissimula, discreto, no rigor de sua prosa. Náo será justamente essa qualidade - do estilo e do homem - que começa a seduzir as novas geraçōes de estudantes de filosofia? $O$ leitor náo encontra aqui nenhum traço do estilo elevado ou sibilino tão na moda, dessa proliferaçáo de imagens que passam por conceitos e que é preciso atravessar penosamente; nada do narcisismo de uma linguagem que se enrola sobre si mesma para dizer a qualidade do autor.

O que aparece como austeridade da linguagem logo denuncia algo mais profundo, que envolve a própria idéia da filosofia. A recusa do jargáo, de toda e qualquer cumplicidade com as modas intelectuais dominantes (por que não dizê-lo? com a ideologia), tal é o nervo da obra. É esta recusa, esta concepçáo essencialmente crítica da filosofia que explica o privilégio atribuído à história dos sistemas filosóficos na estratégia geral do pensamento. Tudo se passa como se, por uma feliz 
convergência, Lívio Teixeira estivesse desde sempre preparado para receber a influência de Martial Guéroult que, quando de sua estada em São Paulo, oferecia o mais alto modelo de uma historiografia filosófica rigorosa. Com esse encontro, era uma tradiçáo que se criava em Sáo Paulo e que, felizmente, perdura até hoje no trabalho dos mais jovens. Que não se veja nesse privilégio atribuído à História algo como o esquecimento da natureza própria da Filosofia. A isto, pode-se responder dando a palavra a Lívio Teixeira: Il est certainement difficile $d$ 'accéder a l'objectivité en bistoire de la Philosopbie. Beaucoup d'bistoriens $n$ 'ont fait que philosopber sur la pbilosophie $d$ 'autres philosophes, ce qui est tout à fait acceptable, mais ne constitue pas une histoire de la philosopbie. En périte, comme l'bistorien doit avoir un esprit philosopbique pour bien comprendre les philosophes, il passe facilement de la comprénension a $l^{\prime}$ interprétation. Et l'bistoire de la philosopbie ne paut pas une beure de peine si elle ne nous conduit pas à la réfléxion personnelle. Cela dit, $l$ 'bistorien doit rester fidele au philosophe qu'il étudie (La Pbilosopbie au Brésil, in Études d'Histoire de la Philosophie, en Hommage da Martial Gutroult", Lib. Fischbacher, p. 210). Só o projeto delirante de uma Ciência Absoluta pode levar a considerar a abordagem tecnológica dos sistemas filosóficos como uma forma de renúncia à filosofia - e a tarefa da crítica não é justamente a de mostrar a falácia desse projeto?

O bom leitor não se equivoca e descobre já nas análises propriamente técnicas das obras de Descartes e de Espinosa algo que transcende imediatamente à pura tecnologia. O fascínio pelo Grande Racionalismo não é aqui o efeito de uma simples opção intelectualista. Arrisquemos uma fórmula - o que interessa a Lívio Teixeira é aquele momento, tensão máxima, em que o racionalismo toca seu próprio limite, ou desmente sua imagem corrente. O limite da razão não aparece como álibi de uma Revelação qualquer e a preocupação moral nada tem de moralismo - de qualquer modo, o que se busca são os signos do concreto (no caso de Descartes, para além do rigor da metafísica da distinçáo entre as substâncias, o reconhecimento do fato da uniáo substancial e da promiscuidade entre o corpo e a alma) ou do investimento histórico da razão (no caso de Espinosa, a verdade política da reflexão metafísicomoral). A busca do sentido da beatitude nas obras de Descartes e de Espinosa é particularmente significativa sob a pena do antigo Pastor. Quer na sua versão estóica, quer na sua versão epicúria, é a idéia de contentamento que dá conteúdo à idéia de beatitude, depurada enfim de seu horizonte místico ou teológico. Comparemos as últimas linhas das duas teses. Uma termina por um texto do escólio final da Ética, no qual Espinosa diz: "O ignorante, além de ser de muitos modos agitado pelas causas exteriores e de náo possuir nunca o verdadeiro contentamento 
interior, vive em quase completa inconsciência de si mesmo, de Deus e das coisas, e cessando de sofrer, cessa também de existir. O sábio, ao contrário, não conhece perturbação interior, mas tendo consciência de si mesmo, de Deus e das coisas, por uma certa necessidade interna, não cessa jamais de existir e de possuir o verdadeiro contentamenton. A outra termina por uma fórmula breve que define o telos da reflexão moral cartesiana: "... vimos que o exercício da virtude tem para Descartes uma incontestável finalidade que é a de alcançarmos a beatitude. Eis-nos agora diante de Epicuro. Em suma, razão e vontade unidas na

Livio Teixeira

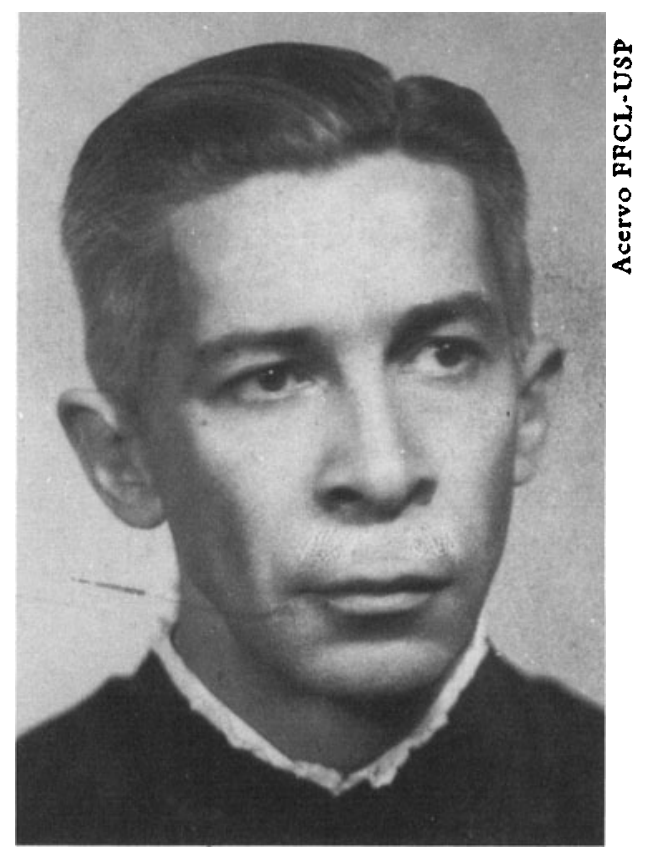

virtude, em busca do maior contentamento que é possivel na vida - eis a moral de Descartes, que é, sem dúvida, uma forma de eudemonismo".

Beatitude natural, portanto, ou terrestre e que se exprime de maneira forte na idéia cartesiana de generosidade. Remédio contra as paixões, a generosidade implica em conhecimento - ao menos esse tipo de conhecimento que, sem atingir embora a clareza e a distinção, é sempre possível no campo da uniáo substancial entre o corpo e a alma. Mas esse remédio é tambem uma paixão. Beatitude natural porque para Descartes como para Espinosa, a virtude não se opóe de maneira absoluta à paixão, ou porque é possível um bom uso das paixóes. Guardamos particularmente aqui a idéia da generosidade, a saber essa paixão particular, a "firme e constante resolução de executar tudo quanto a razăo aconselha 
à firmeza dessa resolução", porque ela nos conduz a algo que - isto sim - a obra náo pode dizer. Ela nos leva para além da história da filosofia, e nos mergulha numa história mais próxima e mais recente; ela situa Lívio Teixeira de uma maneira que as geraçóes mais recentes talvez ignorem e devem conhecer. Penso aqui na crise que atravessando a Universidade, nos últimos anos do magistério de Lívio Teixeira, desafiou e impôs ao Professor responsabilidades mais do que acadêmicas. Há dez anos atrás, aquela firmeza inabalável ou a paixão da generosidade mostrava que esse exemplar trabalhador da filosofia era muito mais do que um scholar. O que explica a força de minha admiraçáo e de meu respeito e - sobretudo agora - minha sensação de perda e desamparo.

Bento Prado Jaimior é professor da Faculdade de Filosofia da Universidade Federal de São Carlos.

Texto extraldo do v. 5, número 6 da revista Discurso (FFLCH-USP, Săo Paulo, 1975, p. 5-7). 